\title{
Theranostics
}

Research Paper

$2011 ; 1: 277-289$

\section{Utilization of I-domain of LFA-I to Target Drug and Marker Molecules to Leukocytes}

\author{
Prakash Manikwar', Bimo A. Tejo ${ }^{1,2}$, Heather Shinogle², David S. Moore ${ }^{3}$, Tahl Zimmerman ${ }^{4}$, Francisco \\ Blanco $^{4,5}$, and Teruna J. Siahaan ${ }^{1,}$ 迥
}

1. Department of Pharmaceutical Chemistry, University of Kansas, Lawrence, KS 66047, USA

2. Current Address: Department of Chemistry, Universiti Putra, Malaysia, 43400 UPM Serdang, Selangor, Malaysia

3. Microscopy and Imaging Laboratory, University of Kansas, Lawrence, KS 66045, USA

4. Unidad de Biología Estructural, CIC bioGUNE, 48160 Derio, Bizkaia, Spain

5. IKERBASQUE, Basque Foundation for Science, 48011 Bilbao, Spain

Corresponding author: Dr. Teruna J. Siahaan, Department of Pharmaceutical Chemistry, The University of Kansas, Simons Research Laboratories, 2095 Constant Avenue, Lawrence, KS 66047, USA. Tel.: (785) 864-7327; Fax: (785) 864-5736; E-mail: siahaan@ku.edu

(C) Ivyspring International Publisher. This is an open-access article distributed under the terms of the Creative Commons License (http://creativecommons.org/ licenses/by-nc-nd/3.0/). Reproduction is permitted for personal, noncommercial use, provided that the article is in whole, unmodified, and properly cited.

Received: 2011.03.14; Accepted: 2011.05.09; Published: 2011.05.10

\begin{abstract}
The long-term objective of this project is to utilize the I-domain protein for the $\alpha$-subunit of LFA-I to target drugs to lymphocytes by binding to ICAM receptors on the cell surface. The short-term goal is to provide proof-of-concept that I-domain conjugated to small molecules can still bind to and uptake by ICAM-I on the surface of lymphocytes (i.e., Raji cells). To accomplish this goal, the I-domain protein was labeled with FITC at several lysine residues to produce the FITC-I-domain and CD spectroscopy showed that the FITC-I-domain has a secondary structure similar to that of the parent I-domain. The FITC-I-domain was taken up by Raji cells via receptor-mediated endocytosis and its uptake can be blocked by anti-I-domain mAb but not by its isotype control. Antibodies to ICAM-I enhance the binding of I-domain to ICAM-I, suggesting it binds to ICAM-I at different sites than the antibodies. The results indicate that fluorophore modification does not alter the binding and uptake properties of the I-domain protein. Thus, I-domain could be useful as a carrier of drug to target ICAM-I-expressing lymphocytes.
\end{abstract}

Key words: ICAM-1; FITC-I-domain; binding; endocytosis; Raji cells

\section{INTRODUCTION}

Intercellular adhesion molecule-1 (ICAM-1) is an Ig-like transmembrane glycoprotein constitutively expressed on several cell types, including leukocytes and dendritic cells. ICAM- 1 is an attractive target for drug delivery to immune cells, since its expression is elevated in several autoimmune disorders [1-7]. Increased ICAM-1 expression has been observed on T-cells isolated from synovial fluid and brain tissue of patients suffering from rheumatoid arthritis and mul- tiple sclerosis, respectively [1-3, 8-9]. Elevated ICAM-1 expression is thought to be a direct consequence of inflammatory cytokines released upon the infiltration of T-cells at the site of destruction. The infiltration of T-cells progressively modifies the clinical outcome of the autoimmune diseases by enhancing the immunogenic response. Cell adhesion molecules (CAM), including ICAM-1, are internalized into the cell cytoplasmic domain via a unique pathway 
referred to as CAM-mediated endocytosis [10-13]. Ligands that bind to CAM can be used to selectively target drugs for intracellular delivery to immune cells expressing these upregulated adhesion molecules. Therefore, I-domain can be utilized to target drugs to cells with upregulated ICAM-1 during inflammation. ICAM-1 targeting offers not only surface binding but also intracellular drug delivery.

The natural counter-receptor of ICAM-1 is leukocyte function associated antigen-1 (LFA- $1, \alpha_{\mathrm{L}} \beta_{2}$, CD11a/CD18), a transmembrane cell surface glycoprotein [14-15]. It belongs to the integrin superfamily of adhesion molecules, widely expressed on immune cell subsets. It is comprised of heterodimeric a $(180 \mathrm{kDa})$ and $\beta(95 \mathrm{kDa})$ subunits, which are non-covalently associated [16-17]. The a-subunit (CD11a) of LFA-1 consists of an amino terminal-inserted-domain (I-domain, approximately 200 amino acids), which is necessary for LFA-1 binding to ICAM-1. The I-domain is structurally located at the top of the a-subunit with a central five-stranded parallel $\beta$-sheet surrounded by seven $\alpha$-helices; it has two important sites for modulation of binding to ICAM-1 [17-18]. The first site is a unique metal ion-dependent adhesion site (MIDAS). The I-domain binds to domain-1 (D1) of ICAM-1 through its MIDAS, which involves coordination of a divalent cation (i.e., $\mathrm{Mg}^{2+}$ or $\mathrm{Ca}^{2+}$ ) via the Asp137, Ser139, Ser141, Thr206 and Asp239 residues [19-20]. The second important site is the I-domain allosteric site (IDAS) [21]. IDAS is an important binding site for small molecule inhibitors of ICAM-1/LFA-1-mediated cell-cell adhesion [22]. Although the I-domain protein has long been studied, I-domain protein alone not conjugated to nanoparticles for potential use as a carrier for drug targeting has not been investigated to date. Therefore, we have begun to investigate the utility of the I-domain to deliver drugs and antigenic peptides to immune cells for controlling autoimmune diseases such as multiple sclerosis, rheumatoid arthritis, and type- 1 diabetes.

In this work, we studied the binding and uptake properties of the fluorescence-labeled I-domain (FITC-I-domain) by ICAM-1 on Raji cells. In the future, I-domain will be conjugated to drug molecules to direct the drugs to cells with overexpressing ICAM-1 for lowering the drug side effects [10-13]. As a model conjugate, several of the lysine residues of the I-domain were derivatized with fluorescein isothiocyanate (FITC) to generate FITC-I-domain. The binding properties of FITC-I-domain to ICAM-1 on Raji cells after incubation at $4{ }^{\circ} \mathrm{C}$ and $37^{\circ} \mathrm{C}$ were characterized by flow cytometry as well as binding modulation using anti-I-domain antibody. The cellular localization of FITC-I-domain was determined by confocal microscope, and the amounts of the I-domain on the cell surface and in the intracellular compartments were determined using fluorescence intensity integrations. Finally, the effect of divalent cations on binding FITC-I-domain to ICAM-1 was also determined.

\section{MATERIALS AND METHODS}

\section{Materials:}

Fluorescein isothiocyanate (FITC) isomer-I, phorbol 12-myristate-13-acetate (PMA), tumor necrosis factor- $\alpha$ (TNF- $\alpha)$ and human IgG were purchased from Sigma-Aldrich (St. Louis, MO). 4',6-Diamidino-2-phenylindole (DAPI) and Alexa Fluor $^{\circledR} 647$ phalloidin were purchased from Molecular Probes (Eugene, OR). Anti-human-ICAM-1 mAb to domain D1 (clone 15.2), mouse IgG1 (clone MOPC31C), anti-human LFA-1 CD11a (clone 38), mouse IgG2a (clone RPC 5), and polyclonal goat anti-mouse IgG/IgM FITC were purchased from Ancell Cooperation (Bayport, $\mathrm{MN}$ ).

Cell culture:

Cells were purchased from ATCC (Rockville, MD) and propagated in an RPMI-1640 medium containing $10 \% \mathrm{v} / \mathrm{v}$ fetal bovine serum, 100 units $/ \mathrm{mL}$ penicillin $\mathrm{G}$ sodium, $100 \mu \mathrm{g} / \mathrm{mL}$ streptomycin sulfate, and $2.0 \mathrm{~g} / 1 \mathrm{NaHCO}_{3}$. The cells were maintained at a density of $1.5 \times 10^{6}$ to $2 \times 10^{6} / \mathrm{mL}$ at $37{ }^{\circ} \mathrm{C}$ in $95 \%$ humidified and $5 \% \mathrm{CO}_{2}$ atmosphere. As necessary, MOLT-3 cells were activated in medium containing PMA for $16 \mathrm{~h}$ or TNF- $\alpha$ for $24 \mathrm{~h}$ with final concentrations of $0.2 \mu \mathrm{M}$ and $10 \mathrm{ng} / \mathrm{mL}$, respectively.

\section{Protein expression and purification:}

The expression of I-domain has been described elsewhere [23]. Briefly, the I-domain DNA sequence was subcloned into pET-11d vector followed by transformation into competent E. coli BL21 cells (Stratagene, La Jolla, CA). Then, the E. coli cells were cultured and the induction of protein overexpression was done using isopropyl D-thio-galactoside (IPTG, Sigma-Aldrich). For isolating the protein, the cell pellets were lysed in $10 \mathrm{~mL}$ of homogenization buffer (HB) using a French press followed by centrifugation $(20000 \times \mathrm{g})$ at $4{ }^{\circ} \mathrm{C}$ for $1 \mathrm{~h}$. The majority of the I-domain was found in the protein pellet. After washing, the cell pellet was resuspended in $15 \mathrm{~mL}$ of denaturing buffer (DB, $6 \mathrm{M}$ guanidine- $\mathrm{HCl}$ and 50 $\mathrm{mM}$ Tris, $\mathrm{pH} 8.5$ ) and incubated for $1 \mathrm{~h}$ at room temperature before centrifugation for $30 \mathrm{~min}$ to remove the remaining cell debris. The supernatant was diluted to a protein concentration of $1 \mathrm{mg} / \mathrm{mL}$ and concentrated with Amicon ${ }^{\circledR}$ ultrafiltration cell (Milli- 
pore) with 5,000 MWCO ultra-filtration membranes. After dialysis against RFB and PBS containing $10 \mathrm{mM}$ $\mathrm{MgSO}_{4}$ at $4{ }^{\circ} \mathrm{C}$, the folded I-domain protein was purified by passing it through a Superdex 200 size-exclusion column (Amersham Biosciences, Pittsburgh, PA) [24]. The protein was concentrated to $10 \mathrm{mg} / \mathrm{mL}$, and the concentration was measured at $280 \mathrm{~nm}$ using an extinction coefficient of $8940 \mathrm{M}^{-1}$ $\mathrm{cm}^{-1}$. The purity of the I-domain was determined by SDS-PAGE gel and confirmed by electrospray ionization mass spectrometry (ESI-MS) with an $\mathrm{m} / \mathrm{z}$ ratio of 1881.2 corresponding to $[\mathrm{M}+11 \mathrm{H}]$. The secondary structure of the folded protein was determined using far-UV circular dichroism (CD).

\section{Conjugation of FITC to the I-domain to give FITC-I-domain:}

The conjugation of FITC to the I-domain protein was performed by following the method previously described [25]. Briefly, one-fourth volume of $1.0 \mathrm{M}$ $\mathrm{NaHCO}_{3} / \mathrm{Na}_{2} \mathrm{CO}_{3}$ buffer $\mathrm{pH} 9.0$ was added to the I-domain solution $(6 \mathrm{mg} / \mathrm{mL})$ followed by addition of a 25-fold molar excess of freshly prepared FITC solution $(5 \mathrm{mg} / \mathrm{mL})$ in DMSO. The mixture was stirred in the dark for $2 \mathrm{~h}$ at $25^{\circ} \mathrm{C}$. At the end of the reaction, the $\mathrm{pH}$ was readjusted to 7.4 using $0.1 \mathrm{~N} \mathrm{HCl}$. Immediately the mixture was purified to separate the conjugated protein from free FITC using a Superdex 200 size-exclusion column. The fractions for the FITC-I-domain were collected and concentrated by ultrafiltration. The concentration of the pure conjugated protein was determined using a UV method described previously [25] by measuring the absorbance at $280 \mathrm{~nm}$ and $495 \mathrm{~nm}$ following the equation:

Concentration of I-domain protein $(\mathrm{mg} / \mathrm{mL})=$ $\left[\mathrm{A}_{280}-\left(0.35 \times \mathrm{A}_{495}\right)\right] / 0.432$

where 0.432 is the $\mathrm{A}_{280}$ of I-domain at a concentration of $1.0 \mathrm{mg} / \mathrm{mL}$ and $0.35 \times \mathrm{A}_{495}$ is the correction factor due to the absorbance of FITC at $280 \mathrm{~nm}$. The purity of the FITC-I-domain conjugate was confirmed by SDS-PAGE gel, and the number of FITC molecules conjugated to the I-domain protein was determined by ESI-MS. The effect of conjugation on the secondary structure was evaluated by comparing the CD spectrum of the I-domain conjugate and that of the parent I-domain.

\section{Flow cytometry:}

Cell preparation: The cell preparation described here was carried out in the same manner for all the experiments described below. Cells from the stock were centrifuged at $500 \times \mathrm{g}$ for $5 \mathrm{~min}$ and then resuspended in sterile PBS to reach a concentration of $5 \times$ $10^{5} / \mathrm{mL}$. Aliquots of $1.0 \mathrm{~mL}$ of the cell suspension were added to $1.5 \mathrm{~mL}$ centrifuge tubes followed by centrifugation at $500 \times \mathrm{g}$. The resulting supernatants were carefully aspirated without disturbing the cell pellets; the pellets were used for the following experiments.

Determination of cell surface expression of ICAM-1 receptor: To decrease the non-specific binding, $20 \mu \mathrm{L}$ of human IgG $(300 \mu \mathrm{g} / \mathrm{mL})$ in FACS buffer containing PBS (10 mM sodium phosphate, $150 \mathrm{mM}$ sodium chloride $\mathrm{pH} 7.2-7.5,1 \% \mathrm{BSA}$, and $0.05 \%$ sodium azide) was added to the cell pellets and incubated for $5 \mathrm{~min}$ at $4{ }^{\circ} \mathrm{C}$. Then, $80 \mu \mathrm{L}$ of anti-CD54 (clone 15.2) or isotype control primary antibody sub-stock ranging from 20 to $0.0006 \mu \mathrm{g} / \mathrm{mL}$ dilutions in FACS buffer was added to the cells, followed by incubation for $45 \mathrm{~min}$ at $4{ }^{\circ} \mathrm{C}$. The cells were washed twice with $0.5 \mathrm{~mL}$ FACS buffer and centrifuged at $500 \times \mathrm{g}$ for $5 \mathrm{~min}$. Into the cell pellet, $50 \mu \mathrm{L}$ of FITC-labeled secondary antibody (1:60 dilution) was added and incubated for 30 min at $4{ }^{\circ} \mathrm{C}$, followed by extensive washing with FACS buffer. The cell pellet was resuspended in 300 $\mu \mathrm{L} 2 \%$ paraformaldehyde/PBS and stored at $4{ }^{\circ} \mathrm{C}$ prior to analysis. The samples were analyzed using a FACScan apparatus (Becton Dickinson, Franklin Lakes, NJ) equipped with CELL QUEST software program. As many as 10,000 cells were counted for every sample during acquisition, and each experiment was done at least in triplicate. Cells without antibody treatment were used as controls. The control histogram was placed within $10^{0}$ to $10^{1}$ on the log scale of fluorescence intensity by adjusting the fluorescence detector. The binding intensities were represented as their relative values to the reference conditions and were determined from the mean values of the histograms for cell number and log fluorescence intensity (mean fluorescence intensity (MFI) corrected for non-specific fluorescence).

Concentration- and temperature-dependent binding of the FITC-I-domain protein: The cell pellet was resuspended in PBS containing increasing concentrations of FITC-I-domain protein from 0 to $52 \mu \mathrm{M}$ at $4{ }^{\circ} \mathrm{C}$ and up to $156 \mu \mathrm{M}$ at $37^{\circ} \mathrm{C}$ and incubated for $60 \mathrm{~min}$. At the end of the incubation period, the cells were washed three times with FACS buffer, and the cell suspension was centrifuged at $500 \times \mathrm{g}$ for $5 \mathrm{~min}$. The cells were fixed using $2 \%$ paraformaldehyde/PBS. The resulting samples were analyzed using flow cytometry, and the MFI was determined as described above.

The effect of anti-LFA-1 mAb on FITC-I-domain binding: Binding of FITC-I-domain to ICAM-1 was also evaluated in the presence of anti-LFA-1 (anti-CD11a) mAb. For blocking studies, $5 \mu \mathrm{M}$ FITC-I-domain was first incubated with equimolar amounts of anti-LFA-1 (clone 38) mAb or its isotype control antibody in buffer for $30 \mathrm{~min}$ at $37^{\circ} \mathrm{C}$; then, 
this mixture was added to cells pretreated with human IgG and incubated for $1 \mathrm{~h}$ at $37^{\circ} \mathrm{C}$. The cell suspension was centrifuged, washed, and fixed before analysis by flow cytometry.

Divalent cation-dependent binding of the FITC-I-domain protein: The cells were incubated for $1 \mathrm{~h}$ at $37^{\circ} \mathrm{C}$ with FITC-I-domain protein $(25 \mu \mathrm{M})$ in the absence and presence of $1.5 \mathrm{mM} \mathrm{CaCl}, \mathrm{MgCl}_{2}, \mathrm{MnCl}_{2}$, $\mathrm{CaCl}_{2}$ /EDTA, $\mathrm{MgCl}_{2}$ /EDTA, or $\mathrm{MnCl}_{2}$ /EDTA in PBS. After incubation, the cells were treated as shown above prior to flow cytometry analysis.

Time- and temperature-dependent binding of the FITC-I-domain protein: The cells were incubated with $100 \mu \mathrm{L}$ of $25 \mu \mathrm{M}$ FITC-I-domain prepared in FACS buffer for $0,5,10,15,30,60,120,180$, and 360 min at 4 ${ }^{\circ} \mathrm{C}$ and $37^{\circ} \mathrm{C}$. After washing and fixing, the cells were subjected to flow cytometry analysis.

\section{Confocal microscopy study:}

Raji cells were centrifuged $(500 \times \mathrm{g})$ for $5 \mathrm{~min}$ and re-suspended in sterile warm PBS to a final concentration of $2.5 \times 10^{5} / \mathrm{mL}$, and $1.0 \mathrm{~mL}$ aliquots were dispensed into nine centrifuge tubes. After centrifugation $(500 \times \mathrm{g})$ and removal of the supernatant solution, $10 \mu \mathrm{L}$ of FACS buffer was added to cells pellets, and the cell suspension was equilibrated for $5 \mathrm{~min}$ at either $4{ }^{\circ} \mathrm{C}$ or $37^{\circ} \mathrm{C}$. Then, $15 \mu \mathrm{L}$ of FITC-I-domain $(100 \mu \mathrm{M})$ was added to the cell suspension and incubated for $0,5,10,15,30,60,120,180$, and $360 \mathrm{~min}$. At each time point, cells were centrifuged, washed twice (with FACS buffer), and fixed with $100 \mu \mathrm{L}$ of $4 \%$ paraformaldehyde in PBS. To the fixed cells, $100 \mu \mathrm{L}$ of $16.5 \mathrm{nM}$ Alexa Fluor ${ }^{\circledR} 647$ phalloidin for actin staining and $12.5 \mu \mathrm{L}$ of $5 \mu \mathrm{M}$ DAPI for nuclear staining were added followed by overnight incubation at $4{ }^{\circ} \mathrm{C}$. The following day, these samples were mounted on a slide and imaged using a Yokugawa CSU-10 spinning disk confocal unit attached to an Olympus IX-81 inverted microscope platform (Olympus America, Inc., Center Valley, PA) Images were captured using a Hamamatsu C9100 electron multiplier $1000 \times 1000$ pixel CCD camera and the SlideBook software package (Intelligent Imaging Innovations, Denver, CO). The resulting images were analyzed using the program CellProfiler to segment regions of interest for measuring fluorescence intensity associated with the membrane and the cytoplasm for each cell examined [26].

\section{Statistical analysis:}

All the values obtained in the above experiments were expressed as mean \pm SE. The differences between groups were tested for statistical significance using Student's t-test. The presence of significant dif- ference is denoted with $p$-values of $<0.05,<0.01$ or $<0.001$.

\section{RESULTS}

\section{Fluorescein conjugation to I-domain:}

The I-domain has been successfully conjugated with fluorescein group at several of the 20 lysine residues to make FITC-I-domain (Figure S1/Scheme 1). Reproducibility of the conjugation was achieved by optimizing the $\mathrm{pH}$, ratio of I-domain/FITC, temperature, and reaction time. The FITC-I-domain was easily separated from the excess FITC using SEC (Fig. 1A). The pure FITC-I-domain shows only a single band on SDS-PAGE when stained with Coomassie blue or upon shining UV light on the gel (lane 4, Fig. 1B). In contrast, the crude reaction product shows two spots by Coomassie blue and three fluorescent spots by UV light (lane 2, Fig. 1B) and the parent I-domain only shows one spot by Coomassie blue and no spot found by UV (lane 3, Fig. 1B).

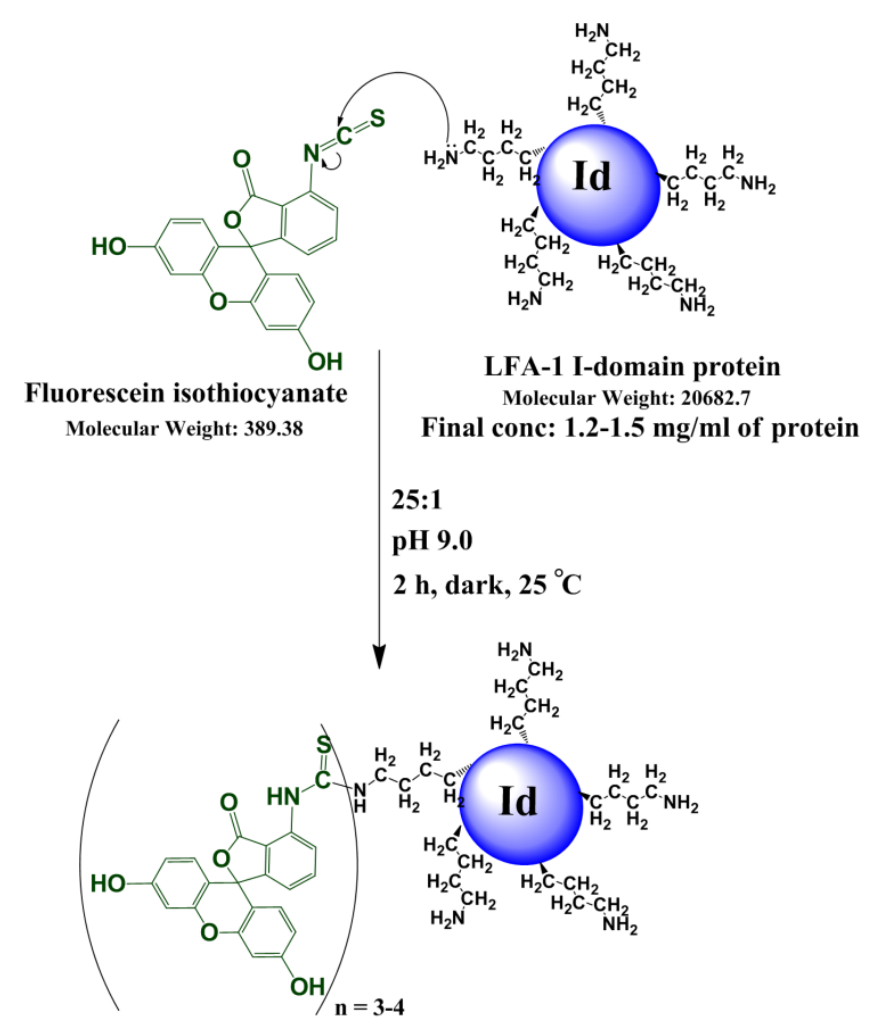

FITC-labeled I-domain protein

Figure SI. Scheme I. Reaction of I-domain protein with FITC along with the reaction conditions listed. 
The ESI-MS data indicate one to seven FITC groups attached to the I-domain with an average of 3.5 FITC groups per I-domain molecule (top panel, Fig. 1C). There is no unconjugated I-domain with a MW of 20,682 found in the MS spectrum (bottom panel, Fig. 1C). The CD spectrum of FITC-I-domain is same as the spectrum of unmodified I-domain (Fig.
1D) indicating that there is no conformational change in the FITC-I-domain. The predicted secondary structure of FITC-I-domain from CD spectra shows $37 \%$ a-helix and $26 \% \beta$-sheet, which very similar to the secondary structure content derived from the crystal structure (i.e., 37\% a-helix and 22\% $\beta$-sheet) [27].

A

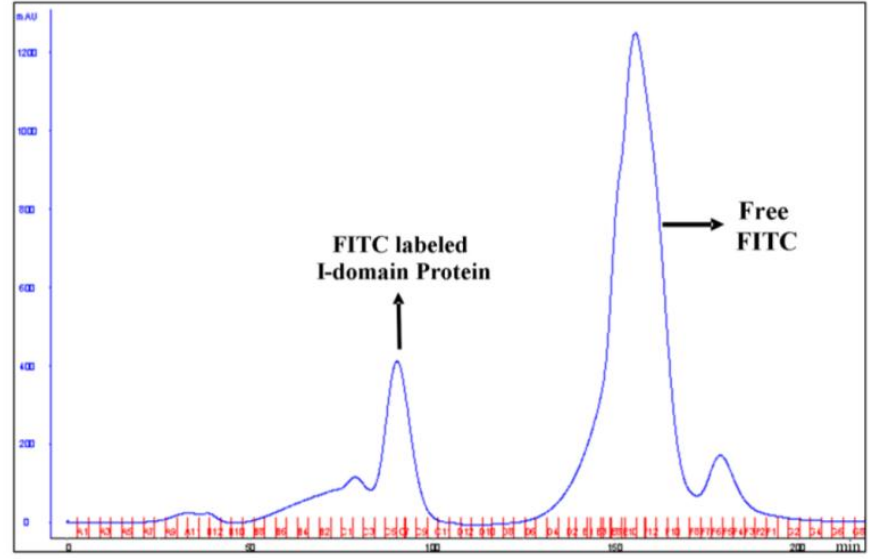

B

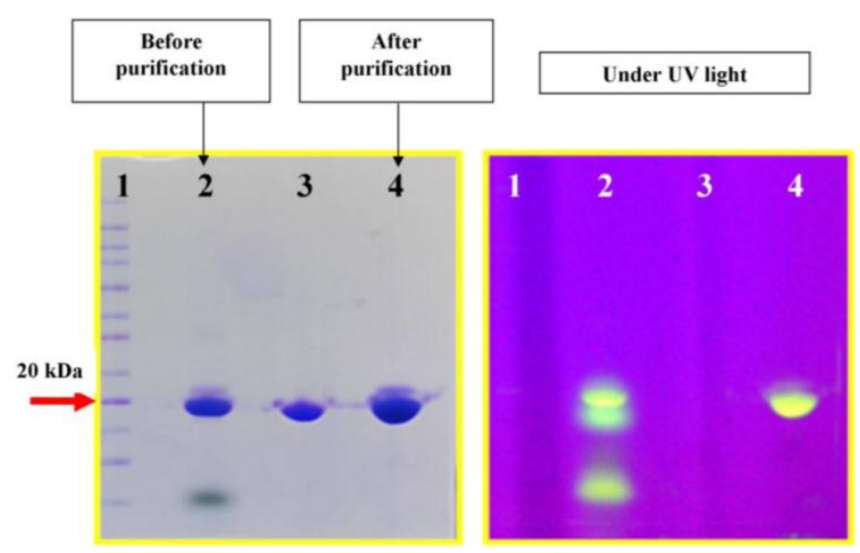

C
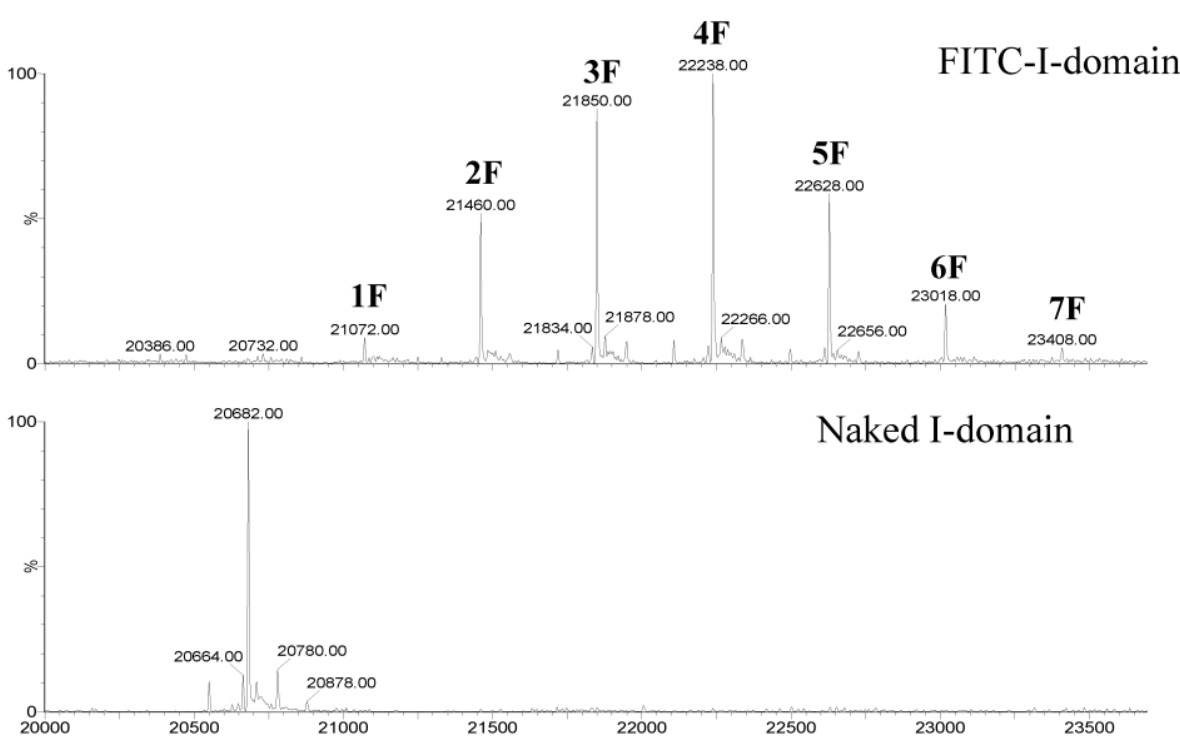
D

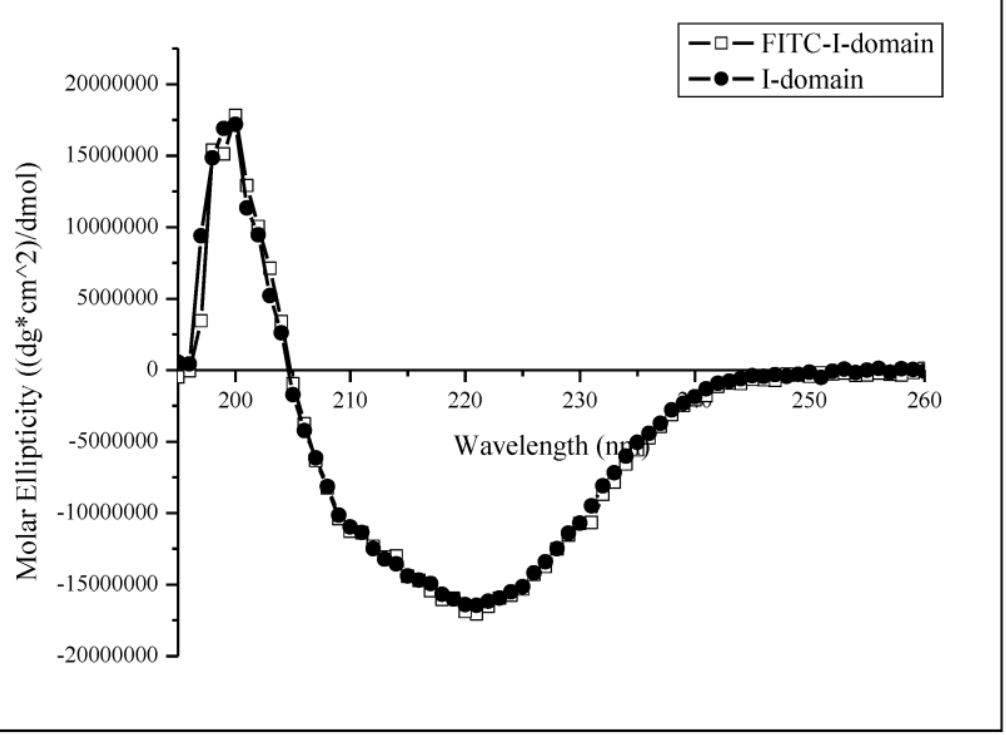

Figure I. A. Separation of the FITC-conjugated I-domain protein from the unreacted (free) FITC using size-exclusion chromatography (SEC). B. SDS-PAGE analysis of pure FITC-I-domain protein after staining with Coomassie blue (left) and before staining under UV light (right): molecular weight marker (lane I), reaction mixture of I-domain protein and FITC (lane 2), unmodified I-domain protein (lane 3), and FITC-conjugated I-domain protein (lane 4). C. ESI-MS analysis of the FITC-I-domain protein (top) and the I-domain protein (bottom). D. CD spectra of unmodified I-domain protein (solid circles), and FITC conjugated I-domain protein (open squares).

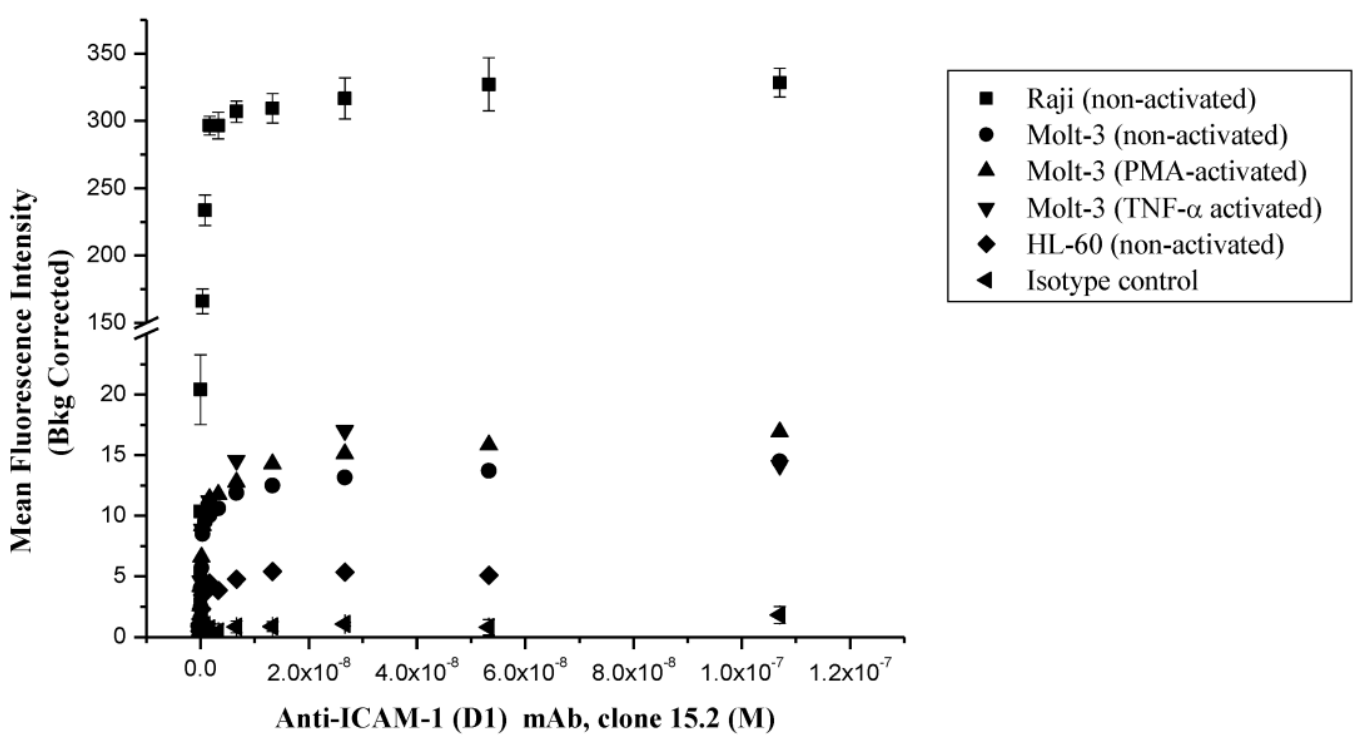

Figure 2. Comparison of the surface expression of ICAM-I receptors in different cell lines using anti-ICAM-I (CD54) mAb 15.2. Data shown from one representative experiment \pm S.E. $(n=3)$ for Raji cells and $(n=1)$ for Molt-3 and HL-60.

Comparison of ICAM-I expression on Raji, HL-60, and Molt-3 cells:

The ICAM-1 expressions on HL-60, Molt-3 T-cells and Raji cells were determined using anti-ICAM-1 D1 (clone 15.2) mAb to select the appropriate cells for FITC-I-domain binding studies (Fig. 2). In all of three cell lines, the anti-ICAM-1 mAb binding increased upon increase in antibody concentration, saturation at high concentrations. The highest ICAM-1 level was found in Raji cells followed by Molt- 3 cells and HL-60 cells. As a negative control, the isotype $\mathrm{mAb}$ did not show any appreciable binding to all three cells. Upon induction with TNF-a or PMA, the expression of ICAM-1 was slightly increased in 
Molt-3; however, the increase in ICAM-1 expression did not match the amount of ICAM-1 on the un-activated Raji cells. Based on these results, the Raji cells were used to perform binding experiments using FITC-I-domain protein.

\section{FITC-I-domain binding to ICAM-I on Raji Cells:}

At $4{ }^{\circ} \mathrm{C}$, the FITC-I-domain exhibited an increase in binding with saturation up to $30 \mu \mathrm{M}$ of added protein when it leveled off (Fig. 3A). At $37{ }^{\circ} \mathrm{C}$, FITC-I-domain binding had two stages (Fig. 3B). The first stage has a tight binding with a steep binding slope for $0-8 \mu \mathrm{M}$ and plateau between 8 and $10 \mu \mathrm{M}$. The second stage a weaker binding of I-domain with a shallow binding slope between 10 and $156 \mu \mathrm{M}$; this binding does not show saturation at a high concentration $(156 \mu \mathrm{M})$, indicating the process of binding and receptor-mediated uptake of FITC-I-domain at 37 ${ }^{\circ} \mathrm{C}$ unlike at $4{ }^{\circ} \mathrm{C}$. Confocal microscopy was used to study the uptake properties of the conjugate.
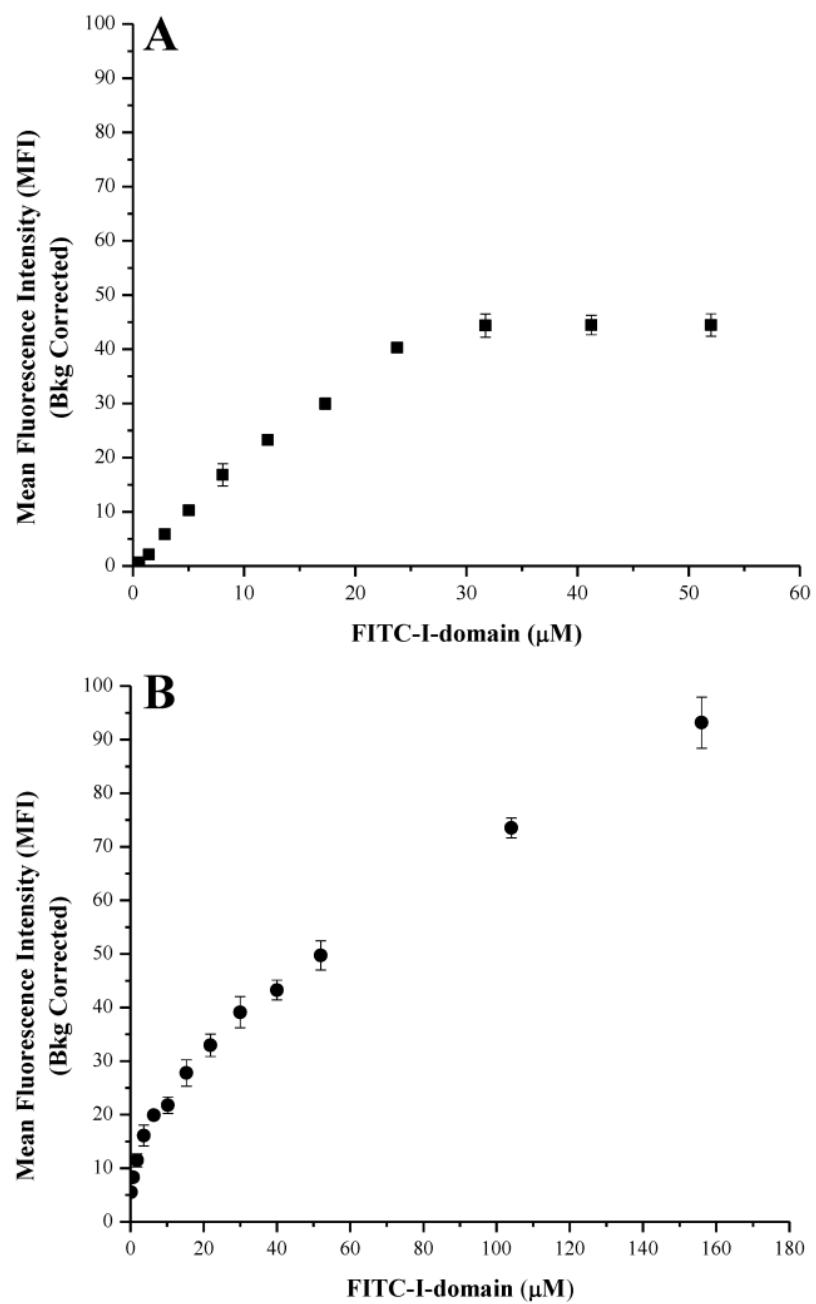

Figure 3. Binding of FITC-I-domain to ICAM-I-expressing Raji cells at $4{ }^{\circ} \mathrm{C}(\mathbf{A})$ and $37{ }^{\circ} \mathrm{C}$ (B). The results are expressed as the mean \pm S.E. $(n=3)$.
The effect of anti-LFA-I mAb on FITC-I-domain binding:

The effect of anti-LFA-1 (anti-CD11a, clone 38) and anti-ICAM-1 mAb on binding of FITC-I-domain to ICAM-1 was determined to access its ICAM-1 specificity. Anti-CD11a mAb binds to I-domain of LFA-1. It blocked $55 \%$ of FITC-I-domain binding to Raji cells; in contrast, the isotype control $\mathrm{mAb}$ did not block the FITC-I-domain binding (Fig. 4). These results are consistent with previously reported data using cell based assay [28] and solid phase ELISA [29].

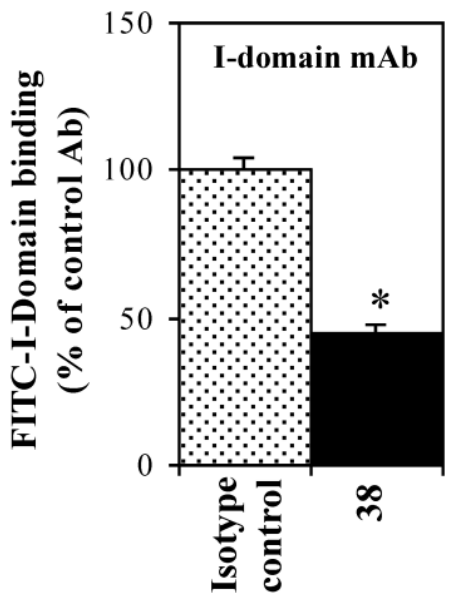

Figure 4. Effect of anti-LFA-I (CDI Ia) I-domain mAb on the binding of FITC-I-domain protein to the ICAM-I receptor expressed on the surface of Raji cells. The results are expressed as the mean \pm S.E. $(n=3)$. There are significant differences in the binding of FITC-I-domain protein; control vs. mAb $38\left({ }^{*} \mathrm{p}<0.01\right)$.

\section{$\mathrm{Ca}^{2+}$ enhances binding of FITC-I-domain to ICAM-I:}

The active state of I-domain interacts with Glu-34 of ICAM-1 via its MIDAS region through a coordination of a divalent metal ion. Thus, the effect of various divalent cations on binding affinity of FITC-I-domain to ICAM-1 on Raji cells was evaluated. $\mathrm{Ca}^{2+}$ significantly enhances binding of FITC-I-domain to the cells compared to $\mathrm{Mg}^{2+}$ or $\mathrm{Mn}^{2+}$ and no divalent cations (Fig. 5). The increase in FITC-I-domain binding could be reversed to normal using $\mathrm{Ca}^{2+}$ and EDTA, suggesting the involvement of $\mathrm{Ca}^{2+}$ in the MIDAS region of FITC-I-domain during binding to ICAM-1. Finally, the presence of EDTA in $\mathrm{Mg}^{2+}-$ or $\mathrm{Mn}^{2+}$-containing media shows binding of FITC-I-domain similar to that of control (absence of cations). These results indicate that $\mathrm{Ca}^{2+}$ is a better coordination cation than $\mathrm{Mg}^{2+}$ or $\mathrm{Mn}^{2+}$ for FITC-I-domain binding to ICAM-1. 


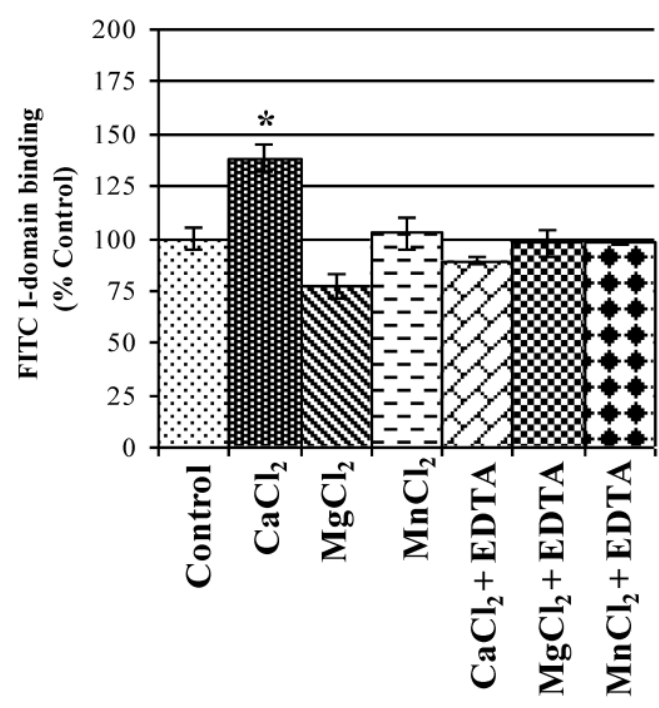

Figure 5. Effect of divalent cations on FITC-I-domain binding to ICAM-I receptors expressed on the surface of Raji cells. The results are expressed as the mean \pm S.E. $(n=$ 3). There are significant differences in the binding of the FITC-I-domain protein; control vs. $\mathrm{CaCl} 2(* \mathrm{p}<0.05)$.

\section{FITC-I-domain uptake by Raji cells:}

The results of concentration-dependent binding studies suggest that FITC-I-domain binds to the cell surface only at $4{ }^{\circ} \mathrm{C}$; however, a combination of binding and uptake of FITC-I-domain is observed at $37^{\circ} \mathrm{C}$ (Fig. 3). To determine the uptake properties, time- dependent binding at $4{ }^{\circ} \mathrm{C}$ and $37^{\circ} \mathrm{C}$ was studied by flow cytometry (Fig. 6). At $37^{\circ} \mathrm{C}, 64 \%$ of binding was observed within 5 min; $100 \%$ binding was arbitrarily assigned to fluorescence intensity at the 360 -min time point with a plateau starting at the 30 -min point. A three-fold decrease in the fluorescence intensity was found upon $4{ }^{\circ} \mathrm{C}$ incubation of the protein, suggesting that the difference in fluorescence intensities at 37 and $4{ }^{\circ} \mathrm{C}$ was due to protein uptake.

To visualize the binding and uptake, Raji cells were incubated with FITC-I-domain at either $4{ }^{\circ} \mathrm{C}$ or $37^{\circ} \mathrm{C}$ with increasing incubation time up to $360 \mathrm{~min}$. This was followed by capturing a confocal Z-section series over a depth of 12-microns. The green fluorescence from the protein could be clearly identified in the cells treated at $37^{\circ} \mathrm{C}$ (Fig. 7A) as early as the 5-min time point. In contrast, only limited green fluorescence was found associated with the cells incubated with the protein at $4{ }^{\circ} \mathrm{C}$ (Fig. 7B).

$\square 4{ }^{\circ} \mathrm{C} \square 37^{\circ} \mathrm{C}$

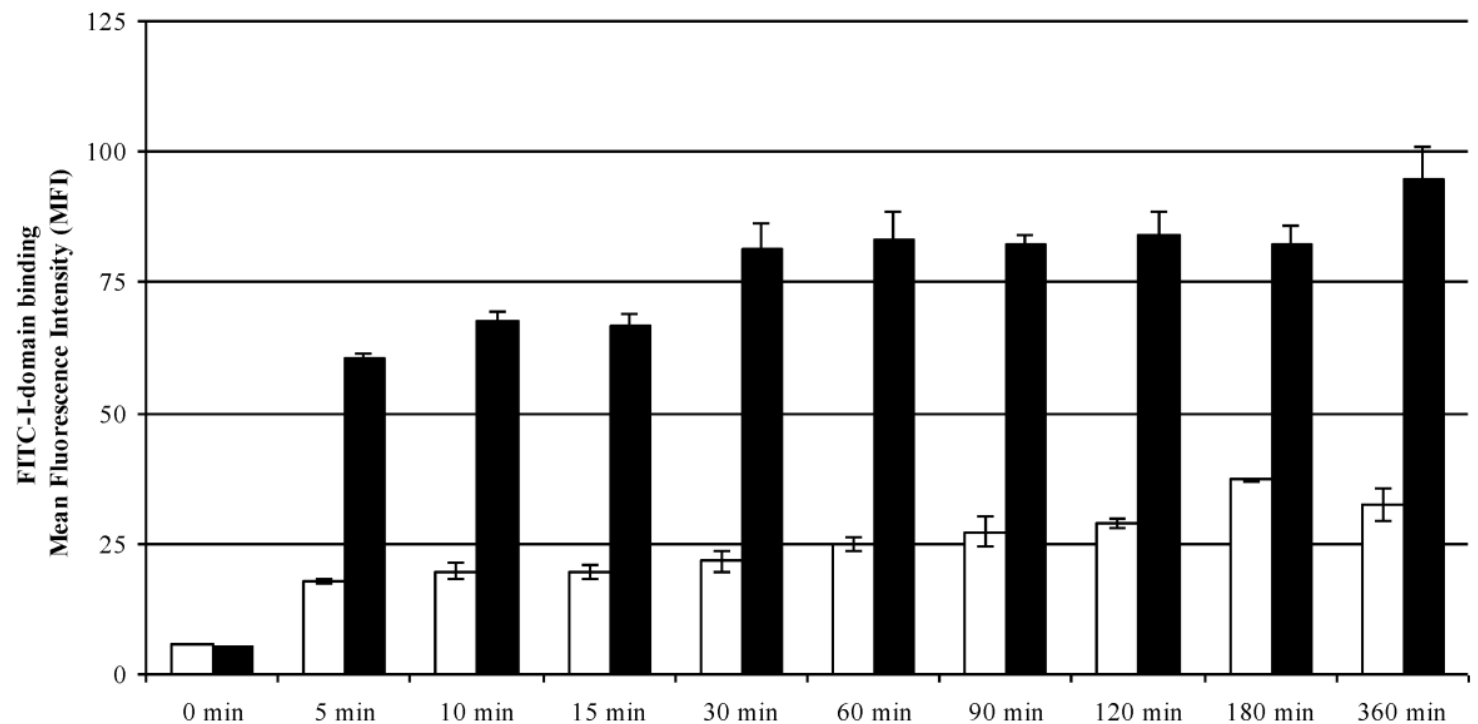

Figure 6. FITC-I-domain protein binding to Raji cells at $37^{\circ} \mathrm{C}$ (closed bars) and $4{ }^{\circ} \mathrm{C}$ (open bars) as a function of time. The values for the mean fluorescence intensity were obtained using flow cytometry. The results are expressed as the mean \pm S.E. $(n=3)$. There are significant differences in the binding of FITC-I-domain protein at 5, 10, 15, 30, 60, 90, I20, I80, and 360 $\min ; 4^{\circ} \mathrm{C}$ vs. $37^{\circ} \mathrm{C}(\mathrm{p}<0.001)$. 

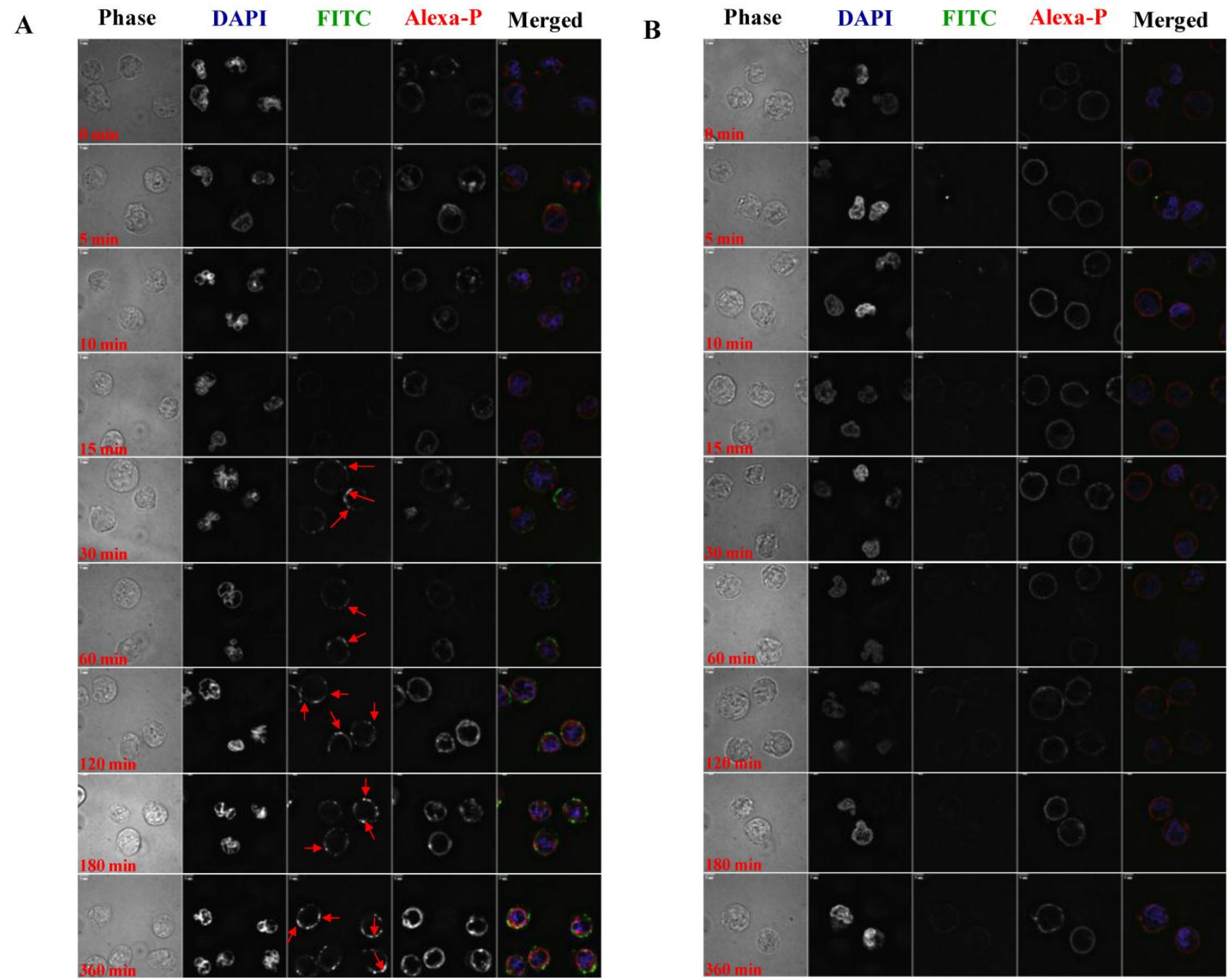

Figure 7. A. Confocal microscopy images of FITC-I-domain binding to ICAM-I on the surface of Raji cells at $37^{\circ} \mathrm{C}$ with increasing incubation time (0, 5, 10, 15, 30,60, 120, 180, and $360 \mathrm{~min})$. Raji cells stained with DAPI (blue) for the nucleus, Alexa Fluor $§ 647$ Phalloidin (red) for actin, and FITC-I-domain (green). Phase contrast image (first row), DAPI (second row), FITC-I-domain (third row), Alexa Fluor ${ }^{\circledR} 647$ Phalloidin (fourth row), and merged image of all the three colors (fifth row). B. Confocal microscopy images of FITC-I-domain binding to ICAM-I on the surface of Raji cells at $4{ }^{\circ} \mathrm{C}$ with increasing

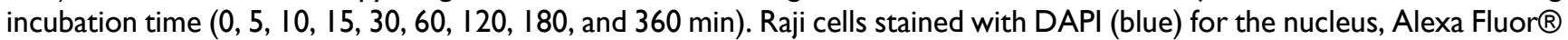
647 Phalloidin (red) for actin, and FITC-I-domain (green). Phase contrast image (first row), DAPI (second row), FITC-I-domain (third row), Alexa Fluor ${ }^{\circledR} 647$ Phalloidin (fourth row), and merged image of all the three colors (fifth row).

To differentiate surface binding and intracellular uptake of FITC-I-domain, the cell nucleus and actin were stained with DAPI and Alexa Fluor ${ }^{\circledR} 647$ phalloidin, respectively. Using the CellProfiler cell image analysis software, captured images were segmented and processed for green fluorescence from FITC-I-domain associated with regions defined as either the whole cell (i.e., region of DAPI staining plus the region of Phalloidin-Alexa Fluor ${ }^{\circledR} 647$ staining) or the cytoplasm (i.e., regions of Phalloidin-Alexa Fluor ${ }^{\circledR}$ 647 staining) alone. The average integrated fluorescence intensity (AIF) values associated with the whole cell upon protein incubation at $37^{\circ} \mathrm{C}$ were increased upon longer incubation time compared to those incubated at $4{ }^{\circ} \mathrm{C}$ (data not shown); these results were consistent with data from flow cytometry. Similarly, the AIF values associated with the cyctoplasm or membranes were higher at $37^{\circ} \mathrm{C}$ than at $4{ }^{\circ} \mathrm{C}$ (data not shown). The AIF intensity values associated with the cytoplasm was slightly lower compared to AIF intensity in the membranes (Fig. 8). These results indicate that FITC-I-domain conjugate binds and internalizes in B-cells at $37^{\circ} \mathrm{C}$. 




Figure 8. FITC-I-domain protein binding to Raji cells at $37^{\circ} \mathrm{C}$. The values for the average integrated fluorescence intensities associated with cytoplasm (open bars) and membrane (closed bars) were obtained from the analysis of the confocal images using cell image analysis software, CellProfiler.

\section{DISCUSSION}

This study is the first to show that I-domain can enter the intracellular space of Raji cells via a receptor-mediated endocytosis process. Previously, cLABL peptide derived from the sequence of I-domain was found in the intracellular space of T-cells upon binding and ICAM-1-mediated endocytosis [30]. Nanoparticles decorated with cLABL peptide or anti-ICAM-1 antibody were also endocytosed into cellular compartments (i.e., endosomes) upon binding to ICAM-1 on the cell surface [13, 31-32]. Recently, I-domain mutants with high affinity to ICAM-1 have been used to target nanoparticles encapsulated with drugs and diagnostic agents to tumor cells with upregulated ICAM-1 [33]. However, I-domain alone and its mutants without conjugation to nanoparticles have not been investigated to deliver drugs to cells with upregulated ICAM-1. Anti-ICAM-1-coated nanoparticles successfully delivered lysosomal enzyme into cells obtained from patients suffering from lysosomal storage disorder [34]. These nanoparticles are endocytosed via a non-classical mechanism upon ICAM-1 clustering, which is called CAM-mediated endocytosis. The CAM-mediated endocytosis is distinct from classical clathrin- or caveolar-mediated internalization as well as from phagocytosis and micropinocytosis processes $[13,35]$.

ICAM-1 has important roles in different pathological conditions such as autoimmune diseases, [36-37] cancer, [36, 38] and atherosclerosis [39]. The level of ICAM-1 expression is increased in several diseases; these include autoimmune disorders (e.g., rheumatoid arthritis, type-1 diabetes, and lupus), malignancies (e.g., multiple myeloma, lymphomas, lung, and pancreatic cancer), inflammatory disorders (e.g., allergic inflammation, asthma), atherosclerosis, ischemia, neurological disorders (e.g., Alzheimer's disease), and allogeneic organ transplantation [36, 40]. Upregulation of ICAM-1 is also found on the endothelium during inflammation, which is influenced by cytokines (i.e., TNF- $\alpha$, IL-1 and IFN- $\gamma$ ), and this upregulation induces adhesion of leukocytes prior to subsequent trans-endothelial migration to the injured tissue [40-43]. Cell surface ICAM-1 molecules serve as endocytosis receptors for human rhinovirus (HRV) and respiratory syncytial virus [44-45]. Thus, the I-domain can be explored as a carrier to target drugs to leukocytes, cancer cells, and inflammatory endothelial cells with up-regulated ICAM-1 receptors. The hope is that the I-domain-drug conjugate can direct the drug molecule to the target pathogenic cells while at the same time avoiding normal cells to minimize the toxic side-effects of the drug. The small drugs can be conjugated to several of the 20 Lys residues of the I-domain. Here, several of these Lys residues of the I-domain were conjugated with FITC groups and still maintained the I-domain conformation (Fig. 1C), ICAM-1-binding (Fig. 3), and uptake properties (Figs. 6-8). We have determined using tryptic mapping, mass spectrometry, and molecular modeling that the FITC-conjugated Lys residues are away from the binding site of I-domain to ICAM-1.

FITC-I-domain binds to ICAM-1 on Raji cells in a 
way that can be inhibited by anti-LFA-1 I-domain $\mathrm{mAb}$ (clone 38), suggesting that this antibody blocks the I-domain binding site to ICAM-1 (Fig. 4). A similar effect of the $\mathrm{mAb}$ was observed in the binding of a GST-tagged I-domain (I-GST) to a surface-coated ICAM-1Fc using a solid-phase ELISA assay [29]. The antibody blocking studies indicate that FITC-I-domain binds to ICAM-1 on Raji cells, and the presence of FITC labels does not alter its binding to ICAM-1.

The binding of FITC-I-domain to ICAM-1 is enhanced by $\mathrm{Ca}^{2+}$ ion but not $\mathrm{Mg}^{2+}$ or $\mathrm{Mn}^{2+}$ ions (Fig. 5); this increase in binding can be reversed upon addition of EDTA. It is interesting that only $\mathrm{Ca}^{2+}$ ion enhances the binding of FITC-I-domain to ICAM-1; this could be due to the fact that $\mathrm{Ca}^{2+}$ has the appropriate size and electrostatic interaction compared to $\mathrm{Mg}^{2+}$ and $\mathrm{Mn}^{2+}$ to coordinate with the MIDAS region of the I-domain and the Glu-34 residue of ICAM-1. Griggs et al. have shown that calcium can bind to the isolated I-domain and can compete with $\mathrm{Mn}^{2+}$, though calcium appears to have a slightly lower affinity [20]. $\mathrm{Mn}^{2+}$ strongly augmented the binding of LFA-1 expressed on the surface of T-cells to its ligand, ICAM-1, [46] suggesting that $\mathrm{Mn}^{2+}$ is able to induce conformational changes in LFA-1 favoring the high affinity state. Binding of $\mathrm{Mg}^{2+}$ with in the I-domain also results in a conformational change such that the C-terminal $\alpha 7$ helix swings away from the central $\beta$-sheet, resulting in a high affinity form of I-domain [47].

Receptor-mediated internalization, along with other technological advances in drug conjugation, may be a useful application for I-domain in targeting drugs to inflammatory diseases, autoimmune diseases, and cancer. Recently, we have successfully conjugated an antigenic peptide with an I-domain protein via a linker. The antigenic peptide-I-domain conjugate effectively suppressed experimental autoimmune encephalomyelitis (EAE) in female SJL/J mice as a model for human multiple sclerosis.

We believe that FITC-I-domain binding to ICAM-1 on the cell surface induces ICAM-1 clustering, further initiating the internalization of the conjugate via an ATP-dependent process. We speculate that this is CAM-mediated endocytosis. The binding sites on ICAM- 1 for HRV and LFA- 1 are distinct with partial overlaps in the binding residues. Studies done using ICAM-1 mutants revealed that the binding site for HRV on ICAM-1 is Gln 58, while for LFA-1 is Glu 34 [48]. Antibodies can selectively bind to the target receptor, but it is not guaranteed that such interactions necessarily result in endocytosis. In vitro and in vivo animal studies done using anti-ICAM-1 have shown that the ICAM antibody internalizes poorly
[49]. In contrast, targeting using LFA-1 I-domain-conjugates is mediated by the comparatively natural interaction between the I-domain and its ligand ICAM-1 receptor. Therefore, I-domain conjugates may offer an alternate solution for selective and effective internalization.

ICAM-1 targeting offers a variety of applications. ICAM-1-targeted isotopes were used for detection of lung inflammation at a very early stage [50]. Liposomes conjugated with anti-ICAM- 1 were able to bind to epithelial and endothelial cells in a dose- and time-dependent manner [51]. Murciano et al. demonstrated the delivery of an anti-ICAM-1 conjugated tissue-type plasminogen activator (tPA) to endothelial cells in vitro and in an in vivo animal model [49] Thus, ICAM-1 targeting has been utilized for imaging, diagnosis, and delivery of therapeutic agents.

\section{CONCLUSIONS}

In this paper, we have shown that the FITC-I-domain can bind to ICAM-1 on the surface of B-cells. The conjugate binding is influenced by the presence of calcium. Further, the conjugate is internalized by ICAM-1 on B-cells, probably via receptor-mediated endocytosis, suggesting that the I-domain can be used to target drugs to the cytoplasmic compartment of cells expressing ICAM-1. In the future, the utility of I-domain proteins in delivering anti-inflammatory, anti-cancer, and antigenic peptides will be investigated.

\section{ACKNOWLEDGEMENT}

This work is supported by the National Institutes of Health (R01-AI-063002 and R56-AI-063002), National Multiple Sclerosis Society, and Institute for Advancing Medical Innovation (The University of Kansas Cancer Center.) We thank Amgen Inc. Predoctoral Fellowships to Prakash Manikwar. We also thank Nancy Harmony for proofreading the manuscript.

\section{Conflict of Interest}

The authors have declared that no conflict of interest exists.

\section{References}

1. Archelos JJ, Previtali SC, Hartung HP. The role of integrins in immune-mediated diseases of the nervous system. Trends Neurosci. 1999; 22: 30-8.

2. Dietrich JB. The adhesion molecule ICAM-1 and its regulation in relation with the blood-brain barrier. J Neuroimmunol. 2002; 128: 58-68.

3. Lee SJ, Benveniste EN. Adhesion molecule expression and regulation on cells of the central nervous system. J Neuroimmunol. 1999; 98: 77-88. 
4. Aoki S, Imai K, Yachi A. Soluble intercellular adhesion molecule-1 (ICAM-1) antigen in patients with rheumatoid arthritis. Scand J Immunol. 1993; 38: 485-90.

5. Campbell IL, Cutri A, Wilkinson D, Boyd AW, Harrison LC. Intercellular adhesion molecule 1 is induced on isolated endocrine islet cells by cytokines but not by reovirus infection. Proc Natl Acad Sci U S A. 1989; 86: 4282-6.

6. Wuthrich RP, Jevnikar AM, Takei F, Glimcher LH, Kelley VE. Intercellular adhesion molecule-1 (ICAM-1) expression is upregulated in autoimmune murine lupus nephritis. Am J Pathol. 1990; 136: 441-50.

7. Hiromatsu Y, Sato M, Tanaka K, Ishisaka N, Kamachi J, Nonaka $K$. Inhibitory effects of nicotinamide on intercellular adhesion molecule-1 expression on cultured human thyroid cells. Immunology. 1993; 80: 330-2.

8. Yokota A, Murata N, Saiki O, Shimizu M, Springer TA, Kishimoto T. High avidity state of leukocyte function-associated antigen-1 on rheumatoid synovial fluid $\mathrm{T}$ lymphocytes. J Immunol. 1995; 155: 4118-24.

9. Hersmann GH, Kriegsmann J, Simon J, Huttich C, Brauer R. Expression of cell adhesion molecules and cytokines in murine antigen-induced arthritis. Cell Adhes Commun. 1998; 6: 69-82.

10. Almenar-Queralt A, Duperray A, Miles LA, Felez J, Altieri DC. Apical topography and modulation of ICAM-1 expression on activated endothelium. Am J Pathol. 1995; 147: 1278-88.

11. Raub TJ, Kuentzel SL. Kinetic and morphological evidence for endocytosis of mammalian cell integrin receptors by using an anti-fibronectin receptor beta subunit monoclonal antibody. Exp Cell Res. 1989; 184: 407-26.

12. Muro S, Muzykantov VR. Targeting of antioxidant and anti-thrombotic drugs to endothelial cell adhesion molecules. Curr Pharm Des. 2005; 11: 2383-401.

13. Muro S, Gajewski C, Koval M, Muzykantov VR. ICAM-1 recycling in endothelial cells: a novel pathway for sustained intracellular delivery and prolonged effects of drugs. Blood. 2005; 105: 650-8.

14. Simmons D, Makgoba MW, Seed B. ICAM, an adhesion ligand of LFA-1, is homologous to the neural cell adhesion molecule NCAM. Nature. 1988; 331: 624-7.

15. Staunton DE, Marlin SD, Stratowa C, Dustin ML, Springer TA. Primary structure of ICAM-1 demonstrates interaction between members of the immunoglobulin and integrin supergene families. Cell. 1988; 52: 925-33.

16. Kishimoto TK, Hollander N, Roberts TM, Anderson DC, Springer TA. Heterogeneous mutations in the beta subunit common to the LFA-1, Mac-1, and p150,95 glycoproteins cause leukocyte adhesion deficiency. Cell. 1987; 50: 193-202.

17. Larson RS, Corbi AL, Berman L, Springer T. Primary structure of the leukocyte function-associated molecule- 1 alpha subunit: an integrin with an embedded domain defining a protein superfamily. J Cell Biol. 1989; 108: 703-12.

18. Qu A, Leahy DJ. Crystal structure of the I-domain from the CD11a/CD18 (LFA-1, alpha L beta 2) integrin. Proc Natl Acad Sci U S A. 1995; 92: 10277-81.

19. Shimaoka M, Xiao T, Liu JH, Yang $Y$, Dong $Y$, Jun CD, et al. Structures of the alpha L I domain and its complex with ICAM-1 reveal a shape-shifting pathway for integrin regulation. Cell. 2003; 112: 99-111.

20. Griggs DW, Schmidt CM, Carron CP. Characteristics of cation binding to the I domains of LFA-1 and MAC-1. The LFA-1 I domain contains a Ca2+-binding site. J Biol Chem. 1998; 273: 22113-9.

21. Huth JR, Olejniczak ET, Mendoza R, Liang H, Harris EA, Lupher MLJr., et al. NMR and mutagenesis evidence for an I domain allosteric site that regulates lymphocyte function-associated antigen 1 ligand binding. Proc Natl Acad Sci U S A. 2000; 97: 5231-6.
22. Weitz-Schmidt G, Welzenbach K, Dawson J, Kallen J. Improved lymphocyte function-associated antigen-1 (LFA-1) inhibition by statin derivatives: molecular basis determined by $\mathrm{x}$-ray analysis and monitoring of LFA-1 conformational changes in vitro and ex vivo. J Biol Chem. 2004; 279: 46764-71.

23. Zimmerman T, Oyarzabal J, Sebastian ES, Majumdar S, Tejo BA, Siahaan TJ, et al. ICAM-1 peptide inhibitors of T-cell adhesion bind to the allosteric site of LFA-1. An NMR characterization. Chem Biol Drug Des. 2007; 70: 347-53.

24. Legge GB, Kriwacki RW, Chung J, Hommel U, Ramage P, Case DA, et al. NMR solution structure of the inserted domain of human leukocyte function associated antigen-1. J Mol Biol. 2000; 295: 1251-64.

25. Schreiber AB, Haimovich J. Quantitative fluorometric assay for detection and characterization of $F_{C}$ receptors. Methods Enzymol. 1983; 93: 147-55.

26. Carpenter AE, Jones TR, Lamprecht MR, Clarke C, Kang IH, Friman $\mathrm{O}$, et al. CellProfiler: image analysis software for identifying and quantifying cell phenotypes. Genome Biol. 2006; 7: R100.

27. Qu A, Leahy DJ. The role of the divalent cation in the structure of the I domain from the CD11a/CD18 integrin. Structure. 1996; 4: 931-42.

28. Landis RC, McDowall A, Holness CL, Littler AJ, Simmons DL, Hogg N. Involvement of the "I" domain of LFA-1 in selective binding to ligands ICAM-1 and ICAM-3. J Cell Biol. 1994; 126: 529-37.

29. Stanley P, Hogg N. The I domain of integrin LFA-1 interacts with ICAM-1 domain 1 at residue Glu-34 but not Gln-73. J Biol Chem. 1998; 273: 3358-62.

30. Yusuf-Makagiansar H, Siahaan TJ. Binding and internalization of an LFA-1-derived cyclic peptide by ICAM receptors on activated lymphocyte: a potential ligand for drug targeting to ICAM-1-expressing cells. Pharm Res. 2001; 18: 329-35.

31. Chittasupho C, Xie SX, Baoum A, Yakovleva T, Siahaan TJ, Berkland CJ. ICAM-1 targeting of doxorubicin-loaded PLGA nanoparticles to lung epithelial cells. Eur J Pharm Sci. 2009; 37: 141-50.

32. Zhang N, Chittasupho C, Duangrat C, Siahaan TJ, Berkland C. PLGA nanoparticle--peptide conjugate effectively targets intercellular cell-adhesion molecule-1. Bioconjugate chemistry. 2008; 19: 145-52.

33. Park S, Kang S, Veach AJ, Vedvyas Y, Zarnegar R, Kim JY, et al. Self-assembled nanoplatform for targeted delivery of chemotherapy agents via affinity-regulated molecular interactions. Biomaterials. 2010; 31: 7766-75.

34. Muro S, Schuchman EH, Muzykantov VR. Lysosomal enzyme delivery by ICAM-1-targeted nanocarriers bypassing glycosylation- and clathrin-dependent endocytosis. Mol Ther. 2006; 13: 135-41.

35. Muro S, Wiewrodt R, Thomas A, Koniaris L, Albelda SM, Muzykantov VR, et al. A novel endocytic pathway induced by clustering endothelial ICAM-1 or PECAM-1. J Cell Sci. 2003; 116: 1599-609.

36. van de Stolpe A, van der Saag PT. Intercellular adhesion molecule-1. J Mol Med. 1996; 74: 13-33.

37. Frank PG, Lisanti MP. ICAM-1: role in inflammation and in the regulation of vascular permeability. Am J Physiol Heart Circ Physiol. 2008; 295: H926-H7.

38. Kobayashi H, Boelte KC, Lin PC. Endothelial cell adhesion molecules and cancer progression. Curr Med Chem. 2007; 14: 377-86.

39. Nakashima Y, Raines EW, Plump AS, Breslow JL, Ross R. Upregulation of VCAM-1 and ICAM-1 at atherosclerosis-prone sites on the endothelium in the ApoE-deficient mouse. Arterioscler Thromb Vasc Biol. 1998; 18: 842-51. 
40. Stanciu LA, Djukanovic R. The role of ICAM-1 on T-cells in the pathogenesis of asthma. Eur Respir J. 1998; 11: 949-57.

41. Sumagin R, Lomakina E, Sarelius IH. Leukocyte-endothelial cell interactions are linked to vascular permeability via ICAM-1-mediated signaling. Am J Physiol Heart Circ Physiol. 2008; 295: H969-H77.

42. Bevilacqua MP. Endothelial-leukocyte adhesion molecules. Annu Rev Immunol. 1993; 11: 767-804.

43. Pober JS, Gimbrone MAJr., Lapierre LA, Mendrick DL, Fiers W, Rothlein $R$, et al. Overlapping patterns of activation of human endothelial cells by interleukin 1, tumor necrosis factor, and immune interferon. J Immunol. 1986; 137: 1893-6.

44. Schober D, Kronenberger P, Prchla E, Blaas D, Fuchs R. Major and minor receptor group human rhinoviruses penetrate from endosomes by different mechanisms. J Virol. 1998; 72: 1354-64.

45. Behera AK, Matsuse H, Kumar M, Kong X, Lockey RF, Mohapatra SS. Blocking intercellular adhesion molecule-1 on human epithelial cells decreases respiratory syncytial virus infection. Biochem Biophys Res Commun. 2001; 280: 188-95.

46. Dransfield I, Cabanas C, Craig A, Hogg N. Divalent cation regulation of the function of the leukocyte integrin LFA-1. J Cell Biol. 1992; 116: 219-26.

47. Ma Q, Shimaoka M, Lu C, Jing $H$, Carman CV, Springer TA. Activation-induced conformational changes in the I domain region of lymphocyte function-associated antigen 1. J Biol Chem. 2002; 277: 10638-41.

48. Staunton DE, Dustin ML, Erickson HP, Springer TA. The arrangement of the immunoglobulin-like domains of ICAM-1 and the binding sites for LFA-1 and rhinovirus. Cell. 1990; 61: 243-54.

49. Murciano JC, Muro S, Koniaris L, Christofidou-Solomidou M, Harshaw DW, Albelda SM, et al. ICAM-directed vascular immunotargeting of antithrombotic agents to the endothelial luminal surface. Blood. 2003; 101: 3977-84.

50. Weiner RE, Sasso DE, Gionfriddo MA, Thrall RS, Syrbu S, Smilowitz HM, et al. Early detection of oleic acid-induced lung injury in rats using (111)In-labeled anti-rat intercellular adhesion molecule-1. J Nucl Med. 2001; 42: 1109-15.

51. Bloemen PG, Henricks PA, van Bloois L, van den Tweel MC, Bloem AC, Nijkamp FP, et al. Adhesion molecules: a new target for immunoliposome-mediated drug delivery. FEBS Lett. 1995; 357: $140-4$. 